\title{
In-Hospital Mortality following Proximal Femur Fractures in Elderly Population
}

\author{
Ganesan G. Ram, MS ${ }^{1}$ Praveen Govardhan, $\mathrm{MS}^{1,2}$ \\ ${ }^{1}$ Department of Orthopaedics, Sri Ramachandra Medical College, \\ Porur, Chennai, India \\ 2 Department of Orthopaedics, Vasanthi Orthopaedic Hospital, \\ Arumbakkam, Chennai, India
}

\begin{abstract}
Address for correspondence Ganesan G. Ram, MS, No 1, Ramachandra Nagar, Department of Orthopaedics, Sri Ramachandra Medical College, Porur, Chennai-600116, India (e-mail: ganesangram@yahoo.com).
\end{abstract}

Surg J 2019;5:e53-e56.

\begin{abstract}
\section{Keywords}

- mortality

- proximal femur

- Parker's mobility score

- replacement surgeries

- elderly

Context In India, hip fracture crude incidence above the age of 50 years was 129 per 100,000 .

Aims The aim of this study is to analyze the in-hospital mortality following proximal femur fractures in elderly Indian population.

Methods and Material The study was done in Sri Ramachandra Medical Center, Chennai, India. Patient's records were retrospectively evaluated for a period of 3 years from January 1, 2015 to January 1, 2018. The inclusion criteria were patients both male and female aged more than 65 years admitted with the diagnosis of neck of femur or intertrochanteric or subtrochanteric fractures. The exclusion criteria were patients having any associated fracture or previous hip fracture history or diagnosed primary or secondary malignancies. To evaluate any surgical delay two groups were formed. After eliminating cases based on exclusion criteria, we had 270 patients for evaluation. Statistical Analysis Used The collected data were analyzed with IBM.SPSS statistics software 23.0 Version. To describe about the data descriptive statistics frequency analysis, percentage analysis were used for categorical variables and the mean and standard deviation (SD) were used for continuous variables. To find the significant difference between the bivariate samples, Student's $t$-test and analysis of variance (ANOVA) were used. The $p$-value of 0.05 is considered as significant level.

Results We had a total of 24 mortalities with 15 males and 9 females. The in-hospital mortality of patients who underwent replacement surgeries for proximal femur fractures was 14 in our study. Sixteen of the in-hospital mortality patients had low Parker's mobility score. Twenty patients had mortality when surgery was delayed more than 48 hours.

Conclusions In-hospital mortality in elderly patients having proximal femur fracture increases significantly if the patient was having low-preoperative mobility status, if surgery was delayed more than 48 hours, and if patient undergoes replacement surgeries.
\end{abstract}

(1) Ganesan G. Ram's ORCID is https://orcid.org/0000-0002-2877$293 X$.

received

February 19, 2019 accepted after revision May 22, 2019
DOI https://doi.org/

10.1055/s-0039-1692995. ISSN 2378-5128.
Copyright @ 2019 by Thieme Medical Publishers, Inc., 333 Seventh Avenue, New York, NY 10001, USA. Tel: +1(212) 584-4662.
License terms

(c) (i) 
In-hospital mortality in proximal femur fracture increases on preoperative mobility status delay in surgery and in prosthetic replacements.

A Proximal femur fractures is a broad term involving the neck of femur, pertrochantric, and subtrochanteric region fractures. ${ }^{1}$ The 90 to $95 \%$ of proximal femur fractures are femoral neck fractures and pertrochanteric fractures and remaining 5 to $10 \%$ are subtrochanteric fractures. ${ }^{2,3}$ Out of all fractures $14 \%$ fractures are proximal femur fractures and it accounts for nearly $72 \%$ of total value for the treatment of fractures. Lifetime risk of hip fracture was $23.3 \%$ for men and $11.2 \%$ for women. ${ }^{4}$ The increase in incidence of hip fractures with increasing the age is a result of an age-related decrease of bone mass in the proximal femur, as well as of the agerelated increase in the incidence of falls. In patients over 65 years of age, fractures of the hip were associated with approximately double the mortality of the general population. For hip fractures Standardized Mortality Rate is 2.0 for women and 3.0 for men. ${ }^{5}$ In India, Hip fracture crude incidence above the age of 50 years was 129 per $100,000 .^{6}$ There are various studies pertaining to the early mortality of proximal femur fractures all over the world and none from subcontinent. The aim of this study was to analyze the inhospital mortality following proximal femur fracture in elderly Indian population.

\section{Subjects and Methods}

The study was done in Sri Ramachandra Medical Centre, a tertiary care referral center in Chennai, South India. Patients' records were retrospectively evaluated for a period of 3 years from January 1, 2015 to January 1,2018. The hospital database has all the necessary documents like diagnosis, comorbidities, surgical intervention, deep vein thrombosis prophylaxis, time in hospital from admission to discharge, or death. This database was linked to individual records of mortality. The inclusion criteria were patients both male and female aged above 65 years admitted with the diagnosis of neck of femur or intertrochanteric or subtrochanteric fractures. Ageing, an inevitable process is commonly measured by chronological age and, as a convention, a person aged 65 years or more is often referred to as "elderly." 7,8 . The modality of fracture fixation was either bipolar hemiarthroplasty or total hip arthroplasty or dynamic hip screw fixation or proximal femur plate or dynamic condylar screw or proximal femur nail. The patients who died during preoperative hospital stay were also included. The exclusion criteria were patients having any associated fracture or previous hip fracture history or diagnosed primary or secondary malignancies. Approval obtained from Sri Ramachandra Medical College institutional ethics committee.

Each patient's number of comorbidities was taken from the patient's records of the previous 2 years. Only the comorbidities like diabetes mellitus, obesity, dementia, Parkinson's disease, hypertension, cerebrovascular diseases, vascular diseases, chronic nephropathy, chronic diseases, rheumatoid arthritis, and osteoporosis were considered. For all the patients included the Charlson's comorbidity index calculated and those having more than 5 were excluded. ${ }^{9}$ To investigate whether there was a difference in mortality between the most common interventions, four groups were included in the analysis. They were conservative group (preoperative death), intramedullary group, extramedullary group, and replacement group. In intramedullary group, patients who underwent proximal femur nail, cervicotrochantric nails were included. In extramedullary group, proximal femur plating, dynamic condylar screw, and dynamic hip screw were included. In replacement group, the hemiarthroplasty, bipolar and total hip arthroplasty patients were included. All the patients, who underwent surgery, were mobilized from 2nd postoperative day either partial or full weight bearing.

The preinjury mobility statuses of all patients were calculated using Parker's mobility score. Patients were divided as low, medium, and high. The Parker's mobility score is an assessment tool that ranks pre fracture mobility on a scale of 0 to 9 . A person with a score of 9 is independent in mobility at home and in the community, whereas someone with a score of 0 is completely dependent for ambulation. ${ }^{10}$ To evaluate any surgical delay two groups were formed. First group contains patients who were operated within 48 hours of injury, while the second group had patients operated after 48 hours of injury. After double verification of data by two separate data analyzers', we had 283 patients who fulfilled the inclusion criteria. After eliminating cases based on exclusion criteria we had 270 patients for evaluation. Out of which 151 were females and 119 were males. We used one-way analysis of variance (ANOVA) F-test for statistical analysis of in hospital mortality with preinjury status of the patients and Student's independent $t$-test for statistical correlation of mortality with various methods of treatment given, sex of the patients, age of the patients, and surgical timing.

\section{Results}

We had a total of 24 mortalities with 15 males and 9 females. The in-hospital mortality following proximal femur fracture in elderly population was $10.03 \%$. Twenty patients had mortality when surgery was done for more than 48 hours (-Table 1). - Table 2 highlights that 14 patients had inhospital mortality when they underwent replacement surgeries for proximal femur fracture. We had 14 patients aged above 70 years died in hospital during the study period. Sixteen of the in-hospital mortality patients had low Parker's mobility score (-Table 3 ).

\section{Discussion}

Hip fractures in elderly increases the morbidity and mortality considerably ${ }^{11,12}$ In-hospital mortality rates ranges between 1 and $10 \%{ }^{12-16}$ Mortality in proximal femur fractures was considered high in male sex and in elderly population. We had 14 patients aged more than 70 years who had in-hospital mortality, which is not statistically significant (-Table 4), which disproves the common belief that as age increases mortality increases. - Table 5 proves that there is no correlation between genders when considering in-hospital mortality 
Table 1 Mortality based on surgical delay

\begin{tabular}{|l|l|l|l|l|l|l|l|l|}
\hline & \multicolumn{2}{|l|}{ Replacement group } & \multicolumn{2}{l|}{ Intramedullary group } & \multicolumn{2}{l|}{ Extramedullary group } & \multicolumn{2}{l|}{ Conservative group } \\
\hline & $\begin{array}{l}\text { Surgery } \\
\text { within 48 h }\end{array}$ & $\begin{array}{l}\text { Surgery } \\
\text { after 48 h }\end{array}$ & $\begin{array}{l}\text { Surgery } \\
\text { within 48 h }\end{array}$ & $\begin{array}{l}\text { Surgery a } \\
\text { fter 48 h }\end{array}$ & $\begin{array}{l}\text { Surgery } \\
\text { within 48 h }\end{array}$ & $\begin{array}{l}\text { Surgery } \\
\text { after 48 h }\end{array}$ & $\begin{array}{l}\text { Death } \\
\text { within 48 h }\end{array}$ & $\begin{array}{l}\text { Death } \\
\text { after 48 h }\end{array}$ \\
\hline $\begin{array}{l}\text { No. of } \\
\text { mortalities } \\
(24)\end{array}$ & 2 & 12 & 1 & 3 & 1 & 1 & - & 4 \\
\hline $\begin{array}{l}\text { Total no } \\
\text { of patients }\end{array}$ & 135 & 75 & & 56 & 4 & \\
\hline
\end{tabular}

Table 2 Correlation of mortality and treatment methods

\begin{tabular}{|l|l|l|l|l|}
\hline $\begin{array}{l}\text { Method of } \\
\text { treatment }\end{array}$ & $\begin{array}{l}\text { Number of } \\
\text { mortality }\end{array}$ & Mean & $\begin{array}{l}\text { Standard } \\
\text { deviation }\end{array}$ & $\begin{array}{l}\text { Student's } \\
\text { independent } \\
t \text {-test }\end{array}$ \\
\hline Replacement & 14 & 23.42 & 25.60 & $\begin{array}{l}t=2.12 ; \\
p=0.05 \\
\text { significant }\end{array}$ \\
\hline $\begin{array}{l}\text { Fixation/ } \\
\text { conservative }\end{array}$ & 10 & 5.90 & 4.97 & \\
\hline
\end{tabular}

Table 3 Mortality based on preinjury status of patients

\begin{tabular}{|l|l|l|l|l|}
\hline $\begin{array}{l}\text { Parker's } \\
\text { score }\end{array}$ & $\begin{array}{l}\text { Number } \\
\text { of } \\
\text { mortality }\end{array}$ & Mean & $\begin{array}{l}\text { Standard } \\
\text { deviation }\end{array}$ & $\begin{array}{l}\text { One-way } \\
\text { ANOVA } \\
\text { F-test }\end{array}$ \\
\hline $\begin{array}{l}\text { Low } \\
(0-4)\end{array}$ & 16 & 21.62 & 24.54 & $\begin{array}{l}\text { F=3.91; } \\
p=0.02 \\
\text { significant }\end{array}$ \\
\cline { 1 - 3 } $\begin{array}{l}\text { Medium } \\
(5-8)\end{array}$ & 6 & 5.16 & 3.06 & \\
\hline High (9) & 2 & 5.00 & 1.41 & \\
\hline Total & 24 & 16.1250 & 21.40563 & \\
\hline
\end{tabular}

Abbreviation: ANOVA, analysis of variance.

Table 4 Correlation of mortality and age of patients

\begin{tabular}{|l|l|l|l|l|}
\hline Age & $\begin{array}{l}\text { Number of } \\
\text { mortality }\end{array}$ & Mean & $\begin{array}{l}\text { Standard } \\
\text { deviation }\end{array}$ & $\begin{array}{l}\text { Student's } \\
\text { independent } \\
t \text {-test }\end{array}$ \\
\hline$>70$ y & 14 & 20.00 & 26.68 & $\begin{array}{l}t=1.05 ; \\
p=0.30 \\
\text { not significant }\end{array}$ \\
\hline $65-70$ y & 10 & 10.70 & 9.29 & \\
\hline
\end{tabular}

Table 5 Correlation of mortality and sex of patients

\begin{tabular}{|l|l|l|l|l|}
\hline Sex & $\begin{array}{l}\text { Number of } \\
\text { mortality }\end{array}$ & Mean & $\begin{array}{l}\text { Standard } \\
\text { deviation }\end{array}$ & $\begin{array}{l}\text { Student's } \\
\text { independent } \\
\text { t-test }\end{array}$ \\
\hline Male & 15 & 14.93 & 17.28 & $\begin{array}{l}t=0.34 ; \\
p=0.73 \\
\text { not significant }\end{array}$ \\
\hline Female & 9 & 18.11 & 28.05 &
\end{tabular}

in proximal femur fractures. Surgical treatment has been established as the gold standard; however, the surgical option remains a dilemma as none of the existing osteosynthesis devices could prove its superiority in previous studies. ${ }^{17,18}$ Parker and Gurusamy in a systematic review of this subject that included 19 trials, internal fixation was found to result in
Table 6 Correlation of mortality with timing of surgery

\begin{tabular}{|l|l|l|l|l|}
\hline $\begin{array}{l}\text { Surgery } \\
\text { time }\end{array}$ & $\begin{array}{l}\text { Number of } \\
\text { mortality }\end{array}$ & Mean & $\begin{array}{l}\text { Standard } \\
\text { deviation }\end{array}$ & $\begin{array}{l}\text { Student's } \\
\text { independent } \\
\text { t-test }\end{array}$ \\
\hline$>48 \mathrm{~h}$ & 20 & 12.75 & 15.30 & $\begin{array}{l}t=1.81 ; \\
p=0.08 \\
\text { significant }\end{array}$ \\
\hline$<48 \mathrm{~h}$ & 4 & 33.00 & 39.68 & \\
\hline
\end{tabular}

lower morbidity in several categories, including blood loss and risk of deep wound infection. ${ }^{19}$ However, patients treated with arthroplasty had significantly lower reoperation rates. No differences were identified in mortality or regaining previous residential status. As per Sathiyakumar et al, retrospective analysis of 9,640 patients undergoing operative repair of a hip fracture open reduction and internal fixation of femoral neck fractures was associated with the highest percentage of total adverse events and major adverse events (primarily death). Whereas hemiarthroplasty was associated with a higher percentage of minor adverse events (e.g., urinary tract infection). ${ }^{20}$ The current study on hospital mortality when a patient underwent replacement was 14 , which is statistically significant when compared to the other methods of treatment as evident from - Table 2.

The patients with lower Parker's mobility score had a statistically significant mortality rate compared to the patients who had higher score ( - Table 3 ). The recommended guidelines for the management of proximal femur fracture were within 2 days. ${ }^{10}$ There was literature support for and against the early management of proximal femur fractures. Some studies have reported no differences in outcomes between early and late management, ${ }^{21}$ while others reported that mortality increases only if surgery is delayed beyond the 4th day. ${ }^{22-25}$ The present study from - Table 6 clearly states that the in-hospital mortality rate increases significantly when surgery was delayed more than 48 hours.

\section{Limitations}

The limitations of the study were retrospective and the study was done in a single center and involving many surgeons with varied experience which may alter the prognosis. The term "elderly population" was very tricky as it may vary based on different ethnicity. Moreover in the study, we didn't analyze the mortalities in different types of replacement surgeries like hemiarthroplasty, bipolar arthroplasty and total hip 
replacement that may affect the outcome. The hospital database from which the patients' details were obtained was not created exclusively for epidemiological analyses.

\section{Conclusion}

Age and sex of the patients do not affect the in-hospital mortality in elderly. In-hospital mortality in elderly patients having proximal femur fracture increases significantly if the patient was having low-preoperative mobility status, if surgery was delayed more than 48 hours and if patient undergoes replacement surgeries.

\section{Conflicting Interest}

None.

\section{References}

1 Daniachi D, Netto AdosS, Ono NK, Guimarães RP, Polesello GC, Honda EK. Epidemiology of fractures of the proximal third of the femur in elderly patients. Rev Bras Ortop 2015;50(04):371-377

2 Braithwaite RS, Col NF, Wong JB. Estimating hip fracture morbidity, mortality and costs. J Am Geriatr Soc 2003;51(03):364-370

3 Filipov O. Epidemiology and social burden of the femoral neck fractures. J IMAB. 2014;20(04):516-518

4 Kanis JA, Johnell O, Oden A, et al. Long-term risk of osteoporotic fracture in Malmö. Osteoporos Int 2000;11(08):669-674

5 Somersalo A, Paloneva J, Kautiainen H, LÖNnroos E, HEinÄNen M, Kiviranta I. Increased mortality after lower extremity fractures in patients $<65$ years of age. Acta Orthop 2016;87(06):622-625

6 Dhanwal DK, Siwach R, Dixit V, Mithal A, Jameson K, Cooper C. Incidence of hip fracture in Rohtak district, North India. Arch Osteoporos 2013;8(1-2):135

7 Singh S, Bajorek B. Defining 'elderly' in clinical practice guidelines for pharmacotherapy. Pharm Pract (Granada) 2014;12(04):489

8 Orimo H, Ito H, Suzuki T, Araki A, Hosoi T, Sawabe M. [Reviewing the definition of elderly]. Nippon Ronen Igakkai Zasshi 2006;43 (01):27-34

9 Charlson ME, Pompei P, Ales KL, MacKenzie CR. A new method of classifying prognostic comorbidity in longitudinal studies: development and validation. J Chronic Dis 1987;40(05):373-383

10 Schnell S, Friedman SM, Mendelson DA, Bingham KW, Kates SL. The 1-year mortality of patients treated in a hip fracture program for elders. Geriatr Orthop Surg Rehabil 2010;1(01):6-14

11 Wolinsky FD, Fitzgerald JF, Stump TE. The effect of hip fracture on mortality, hospitalization, and functional status: a prospective study. Am J Public Health 1997;87(03):398-403
12 Bentler SE, Liu L, Obrizan M, et al. The aftermath of hip fracture: discharge placement, functional status change, and mortality. Am J Epidemiol 2009;170(10):1290-1299

13 Frost SA, Nguyen ND, Black DA, Eisman JA, Nguyen TV. Risk factors for in-hospital post-hip fracture mortality. Bone 2011;49(03): 553-558

14 Orces $\mathrm{CH}$. In-hospital hip fracture mortality trends in older adults: the National Hospital Discharge Survey, 1988-2007. J Am Geriatr Soc 2013;61(12):2248-2249

15 Wu TY, Jen MH, Bottle A, Liaw CK, Aylin P, Majeed A. Admission rates and in-hospital mortality for hip fractures in England 1998 to 2009: time trends study. J Public Health (Oxf) 2011;33(02): 284-291

16 Alzahrani K, Gandhi R, Davis A, Mahomed N. In-hospital mortality following hip fracture care in southern Ontario. Can J Surg 2010; 53(05):294-298

17 Saudan M, Lübbeke A, Sadowski C, Riand N, Stern R, Hoffmeyer P. Pertrochanteric fractures: is there an advantage to an intramedullary nail?: a randomized, prospective study of 206 patients comparing the dynamic hip screw and proximal femoral nail J Orthop Trauma 2002;16(06):386-393

18 Utrilla AL, Reig JS, Muñoz FM, Tufanisco CB. Trochanteric gamma nail and compression hip screw for trochanteric fractures: a randomized, prospective, comparative study in 210 elderly patients with a new design of the gamma nail. J Orthop Trauma 2005;19(04):229-233

19 Parker MJ, Gurusamy K. Internal fixation versus arthroplasty for intracapsular proximal femoral fractures in adults. Cochrane Database Syst Rev 2006;(04):CD001708

20 Sathiyakumar V, Greenberg SE, Molina CS, Thakore RV, Obremskey WT, Sethi MK. Hip fractures are risky business: an analysis of the NSQIP data. Injury 2015;46(04):703-708

21 Scottish Intercollegiate Guidelines Network (SIGN). Management of elderly people with fractured hip. Edinburgh: SIGN; 1997. (SIGN publication no. 15). Accessed 21 May 2009

22 Smektala R, Endres HG, Dasch B, et al. The effect of time-tosurgery on outcome in elderly patients with proximal femoral fractures. BMC Musculoskelet Disord 2008;9:171

23 Franzo A, Francescutti C, Simon G. Risk factors correlated with post-operative mortality for hip fracture surgery in the elderly: a population-based approach. Eur J Epidemiol 2005;20(12): 985-991

24 Moran CG, Wenn RT, Sikand M, Taylor AM. Early mortality after hip fracture: is delay before surgery important? J Bone Joint Surg Am 2005;87(03):483-489

25 Castronuovo E, Pezzotti P, Franzo A, Di Lallo D, Guasticchi G. Early and late mortality in elderly patients after hip fracture: a cohort study using administrative health databases in the Lazio region, Italy. BMC Geriatr 2011;11:37-43 